\title{
HIV maternal-fetal transmission in a low resources setting in the outskirts of Buenos Aires, Argentina M Hojman*1, F Murano ${ }^{2}$, G Manonelles ${ }^{3}$, M Maldonado ${ }^{1}$, N Ahmed ${ }^{1}, \mathrm{M}$ Sanchez Vera ${ }^{2}$ and M Prieto ${ }^{2}$
}

\author{
Address: ${ }^{1}$ Hospital "Dr. Raul Larcade", San Miguel, Argentina, ${ }^{2}$ Hospital Provincial 'P.V. de Cordero', San Fernando, Argentina and ${ }^{3}$ Hospital \\ Comunal de Tigre, Tigre, Argentina \\ * Corresponding author
}

\author{
from Ninth International Congress on Drug Therapy in HIV Infection \\ Glasgow, UK. 9-13 November 2008 \\ Published: 10 November 2008 \\ Journal of the International AIDS Society 2008, I I (SuppI I):P227 doi:I0.I I86/I758-2652-I I-SI-P227
}

This abstract is available from: http://www.jiasociety.org/content/I I/SI/P227

(c) 2008 Hojman et al; licensee BioMed Central Ltd.

\section{Purpose of the study \\ HIV maternal-fetal transmission (MFT-HIV) in Argentina is around 6\%, one of the highest rates in Latin America. Most cases occur in the outskirts of Buenos Aires, a highly populated, low resources setting where the hospitals of this study are located. Our objective was to assess reasons, risk factors and percentage of MFT-HIV, characteristics of HIV+ pregnant women (PW), and evaluation of preven- tive measurements.}

\section{Methods}

Prospective, descriptive, study of HIV+ PW and their newborns (NB) from 1997 to 2006 in two hospitals of Buenos Aires Province, Argentina.

\section{Summary of results}

211 HIV+ mother-child binomium were evaluated, and 171 (81\%) NB were studied: nine acquired HIV (5.26\%) (at least one PCR+ or ELISA+ at 18 months). Mean mother's age 26.8 years $(15-40)$ : MFT+: 29 years vs. MFT: 27.2 years $(p=0.31)$. Way of HIV acquisition: sexual $(96.2 \%)$, intravenous drug use $(2.5 \%)$, blood transfusion $(1.3 \%)$; all TMF+ sexual $(\mathrm{p}=0.59)$.

Seventy-three $(42.7 \%)$ women began HIV follow-up previous to pregnancy: $6 \mathrm{TMF}+\mathrm{vs} .67 \mathrm{TMF}-(\mathrm{p}=0.13) ; 19$ (11.1\%) before 14 weeks: all NFT-; 36 (21\%) between 1528 weeks: all NFT-, 32 (18.7\%) after 29 weeks: all NFT-; and $11(6.4 \%)$ post-partum: $2 \mathrm{TMF}+$ vs. 9 TMF- $(\mathrm{p}=$ 0.0047).

During pregnancy, 134 (63.5\%) women received ART: AZT (11.5\%), AZT-ddI (0.6\%), AZT-3TC (3.6\%), AZT3TC-IDV/RTV (1.2\%), AZT-3TC-LPV/RTV (0.6\%), AZT3TC-NFV (7.9\%), AZT-3TC-NVP (66.6\%), AZT-3TC-SQV/ RTV (7.9\%); 34 MFT- and 3 MFT+ did not receive (p = 0.38 ) Viral load (VL) measured previous to labor in 73 (42.7\%) women: $43<1000(58.9 \%)$. VL was not available in 89 MFT- and 9 MFT+ $(\mathrm{p}=0.02) .109(63.7 \%)$ were elective Caesarean: 56 MFT- vs. 3 MFT+ $(\mathrm{p}=0.11)$ In 145 $(84.4 \%)$ cases, i.v. AZT was administered intra-labor; 4 MFT+ vs. 22 MFT- did not receive intra-partum AZT ( $\mathrm{p}=$ $0.042)$ One NB died perinatally $(0.58 \%)$. Mean gestational age: 37.9 weeks. MFT-: 38.0 vs. MFT+: $39.1(\mathrm{p}=$ $0.0302)$; eight $(4.67 \%)$ NB premature, all MFT- ( $\mathrm{p}=$ $0.49)$. Mean birth weight $2,895.7 \mathrm{~g}(1,450-4,500)$. MFT-: $2,884 \mathrm{~g}$ vs. MFT $+3,093 \mathrm{~g}(\mathrm{p}=0.0938) ; 42 \mathrm{NB}(24.6 \%)$ presented low birth weight; MFT-: 41 vs. MFT+: 1 (p = $0.33)$.

163 (95.3\%) NB received ART: AZT(93.9\%), AZT-3TCNVP (5.52\%), AZT-NVP (0.6\%); 6 MFT- and 2 TMF+ did not $(\mathrm{p}=0.013)$. Nine $(5.26 \%)$ NB were breastfed, 7 MFTvs. $2 \mathrm{MFT}+(\mathrm{p}=0.019)$. 


\section{Conclusion}

Beginning of HIV follow-up post-partum, availability of VL result at the moment of delivery, AZT intra-partum, higher gestational age, lack of administration of ART to the newborn, and breastfeeding were significant for HIVMFT. It is mandatory to re-affirm the importance of the fulfillment of measures destined to diminish the probability of HIV-MFT.

Publish with Bio Med Central and every scientist can read your work free of charge

"BioMed Central will be the most significant development for disseminating the results of biomedical research in our lifetime. " Sir Paul Nurse, Cancer Research UK

Your research papers will be:

- available free of charge to the entire biomedical community

- peer reviewed and published immediately upon acceptance

- cited in PubMed and archived on PubMed Central

- yours - you keep the copyright 